\title{
Editorial Comment: Role of preoperative MR volumetry in patients with renal cell carcinoma for prediction of postoperative renal function after radical nephrectomy and nephron sparing surgery
}

\author{
Luciano A. Favorito ${ }^{1,2}$ \\ ${ }^{1}$ Professor Associado da Unidade de Pesquisa Urogenital - Universidade do Estado de Rio de Janeiro - \\ Uerj, Rio de Janeiro, RJ, Brasil, ${ }^{2}$ Serviço de Urologia, Hospital da Lagoa Federal, Rio de Janeiro, RJ, \\ Brasil
}

Lal and Collegues from India (1) in a interesting study shows the role of MRI for predicting postoperative renal function by preoperative estimation of renal parenchymal volume and correlation with glomerular filtration rate (GFR) in a prospective observational study in 30 patients with renal cancer. The MRI volumetry was used to estimate the renal parenchymal volume and shows that preoperative residual parenchymal volume on MRI renal volumetry correlates well with postoperative GFR in patients with RCC undergoing radical nephrectomy or nephron sparing surgery. Partial nephrectomy (open, laparoscopic or robotic) is considered the gold standard for treating localized renal tumors (2-6). Renal parenchymal preservation is the great objective of the partial nephrectomy. Methods that assist in programming the surgical preservation are very well coming. Recently interesting papers about the 3D printed technology shows a lot of applications in kidney surgery (7-9). Papers using the preoperative estimation of renal parenchymal volume with MRI can help a lot in planning the partial nephrectomy.

\section{CONFLICT OF INTEREST}

None declared.

\section{REFERENCES}

1. Lal H, Singh P, Yadav P, Singh A, Singh UP, Sureka SK, Kapoor R. Role of preoperative MR volumetry in patients with renal cell carcinoma for prediction of postoperative renal function after radical nephrectomy and nephron sparing surgery. Int Braz J Urol. 2020;46:234-41.

2. Volpe A, Cadeddu JA, Cestari A, Gill IS, Jewett MA, Joniau S, et al. Contemporary management of small renal masses. Eur Urol. 2011;60:501-15.

3. Porreca A, D’Agostino D, Dente D, Dandrea M, Salvaggio A, Cappa E, et al. Retroperitoneal approach for robot-assisted partial nephrectomy: technique and early outcomes. Int Braz J Urol. 2018;44:63-8.
4. Lanchon C, Arnoux V, Fiard G, Descotes JL, Rambeaud JJ, Lefrancq JB, et al. Super-selective robot-assisted partial nephrectomy using near-infrared flurorescence versus early-unclamping of the renal artery: results of a prospective matched-pair analysis. Int Braz J Urol. 2018;44:53-62.

5. Tachibana $H$, Takagi $T$, Kondo $T$, Ishida $H$, Tanabe $K$. Comparison of perioperative outcomes with or without renorrhaphy during open partial nephrectomy: A propensity score-matched analysis. Int Braz J Urol. 2018;44:467-74.

6. Bertolo R, Fiori C, Piramide F, Amparore D, Porpiglia F. The preoperative stratification of patients based on renal scan data is unable to predict the functional outcome after partial nephrectomy. Int Braz J Urol. 2018;44:740-9. 
7. Lee H, Nguyen NH, Hwang SI, Lee HJ, Hong SK, Byun SS Personalized 3D kidney model produced by rapid prototyping method and its usefulness in clinical applications. Int Braz J Urol. 2018;44:952-7.

8. Mercader C, Vilaseca A, Moreno JL, López A, Sebastià MC, Nicolau $C$, et al. Role of the three-dimensional printing technology incomplex laparoscopic renal surgery: a renal tumor in a horseshoe kidney. Int Braz J Urol. 2019;45:1129-35.

\section{Luciano A. Favorito, MD, PhD}

Unidade de Pesquisa Urogenital

da Universidade do Estado de Rio de Janeiro - UERJ,

Rio de Janeiro, RJ, Brasil

E-mail: lufavorito@yahoo.com.br
9. Atalay HA, Canat HL, Ülker V, Alkan İ, Özkuvanci Ü, Altunrende F. Impact of personalized three-dimensional -3Dprinted pelvicalyceal system models on patient information in percutaneous nephrolithotripsy surgery: a pilot study. Int Braz J Urol. 2017;43:470-5.
ARTICLE INFO

iD Luciano A. Favorito http://orcid.org/0000-0003-1562-6068

Int Braz J Urol. 2020; 46: 242-3

October 30, 2019

Accepted:

November 05, 2019 